\title{
PINEAPPLE FRUIT COLLAPSE: NEWLY EMERGING DISEASE OF PINEAPPLE FRUIT IN LAMPUNG, INDONESIA
}

\author{
Joko Prasetyo \& Titik Nur Aeny \\ Plant Clinic Laboratory \\ Department of Agrotechnology, Faculty of Agriculture University of Lampung, \\ Bandar Lampung, Indonesia 35145 \\ E-mail: jkdwiprasetyo21@gmail.com
}

\begin{abstract}
Pineapple fruit collapse: newly emerging disease of pineapple fruit in Lampung, Indonesia Recently, a new disease on pineapple fruit has occurred in Lampung. Symptoms of the disease are complex. Fruits rotted and exuded copious liquid from the inter- fruitlet tissues accompanied by gas bubbles. Open spaces were formed inside the rotten fruit. Dissection of diseased fruit showed many cavities within its sceletal fibres and bad odour was exerted from the rotten tissues. A bacterial entity was isolated from the diseased materials. In a pathogenicity test, the isolated bacteria caused the same symptom as mentioned. In the growing-on test the crown of the heavily infected fruit showed heart rot symptom. Those indicated that the disease was pineapple fruit collapse. Both symptoms were known related to the same causal agent, Erwinia chrysanthemi (pineapple strain Dickeya sp.). In our opinion, this is the first report of pineapple fruit collapse in Indonesia.
\end{abstract}

Key words: pineapple fruit collapse, pineapple heart rot, and Erwinia chrysanthemi

\section{INTRODUCTION}

In October 2013 our Plant Clinic Laboratory recieved samples of some diseased pineapple fruits from Nusantara Tropical Farm (NTF) Company located in Way Jepara area, East Lampung District. The company has never experienced the disease before but recently has experienced heavy loss due to disease in the plantation. In 2012 the loss reached 50\%. Two to three weeks before ripening, the fruits rotted and collapsed immediately. This article briefly reports the symptomatology and etiology of the disease.

\section{MATERIALS AND METHODS}

In order to diagnose the disease, some steps were conducted, i.e. observation of diseased fruits, isolation of the causative agent, pathogenicity test, and growingon test. Observation of diseased fruits was done by comparing appearance of the outer and the inner parts of diseased fruit with that of the healthy fruit. To investigate the inner part of the fruit, the diseased fruits were crossly and tranversely dissected. Diseased tissues showing early soft rot were sampled and cut into small pieces, desinfected in chlorox for 1 minute, and suspended in $5 \mathrm{ml}$ sterile water. The suspension was then streaked on the TZC media and incubated for 24 hours. One ooze of recovered bacteria was suspended in $10 \mathrm{ml}$ sterile water and injected into the inner part of immature-healthy fruit using a sterile syringe. The inoculated fruits were incubated for five days. The crowns of heavily infected fruits were grown in sterilized soil for 4 weeks to observe development of heart rot to ascertain its association with Erwinia chrisanthemi.

\section{RESULTS AND DISSCCUSION}

Symptoms. The diseased fruits collected from the field showed various symptoms as followed: the colour of the fruit skin was olive green and the fruit surface produced liquid substance accompanied by bubbles of gas (Figure 1a). Cross section of the diseased fruit showed that the inner part of the fruit rotted, developed cavities (Figure1b), and produced tipically bad odorur. It was different from the healthy-mature fruit that produced pleasant odour. The rotting appearance could reach the fruit core and then the crown base tissues (Figure 2). Thus, the pathogen might contaminate this planting material. 
Pathogen. We successfully isolated bacterial colonies from the rotten fruit specimen. On TZC media the bacteria formed whitish colonies with reddish appearance in the center (Figure 3 ). Further investigation to characterize the bacteria is still going on in our laboratory.

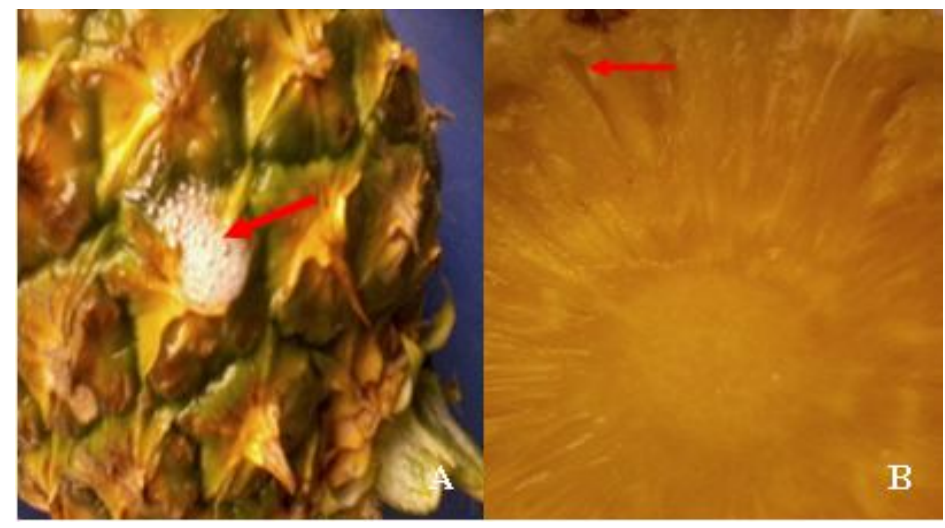

Figure 1. Fruit skin surface appeared wet and produced bubbles (A), many cavities were formed within its sceletal fibres (B)

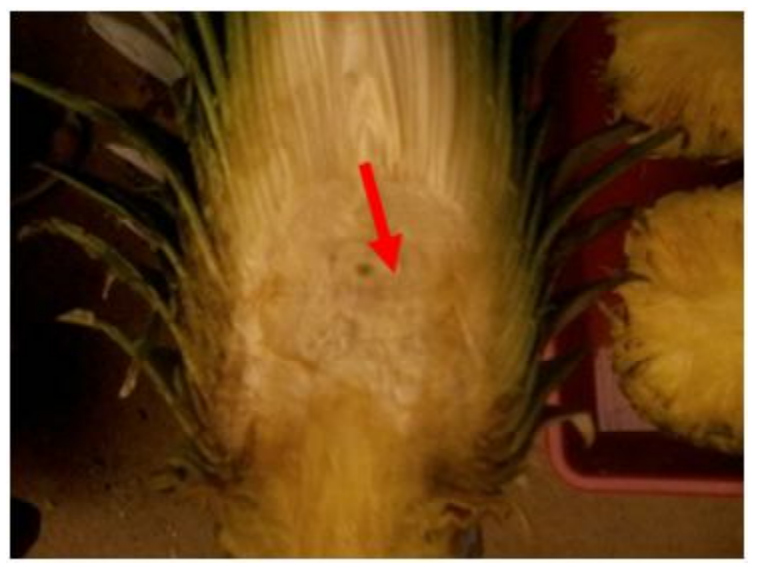

Figure 2. The rotting part reached the crown base area

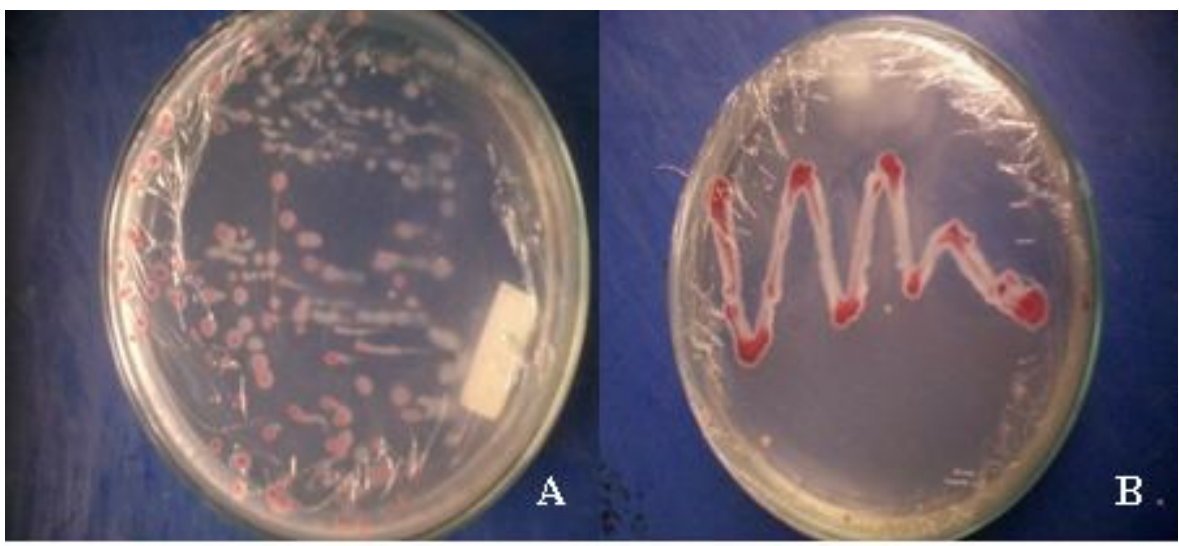

Figure 3. The growth of bacterial colonies (A), and bacterial streak (B) on TZC media 
Pathoginicity Test . After ten days of incubation, the inoculated fruits rotted and produced similar symptoms as described earlier (Figure 4 ).

Growing-on Test. The crown from the heavily infected fruit that has been incubated on soil for 4 weeks showed a heart rot symptom. The crown stem also rotted and the leaves could easily be detached from crown axyl (Figure 5). Their rotted tissues also produced typically bad odour as was in the rotted fruits. The observed sympthom and tested to confirm that the disease be the pineapple fruit collapse. Pineapple fruit collapse is commonly caused by Erwinia chrysanthemi (pineapple strain Dickeya sp.) (Kaneshiro et al., 2008). However, Korres et al. (2010) from Brazilia suggested that pineapple fruit collapse was caused by Klesiella sp. in combination with yeasts. We suspected that the bacteria is E. chrysanthemi for two reasons. During 2011, Lampung (Indonesia) has imported pineapple planting materials from the Phillipine, where the disease was known endemic in the country (Kaneshiro et al., 2008). The other reason is that the bacteria are capable of inciting two kinds of diseases, i.e. fruit collapse and heart rot of pineapple both of which are shown and purcase (Figure 2, Figure 5).
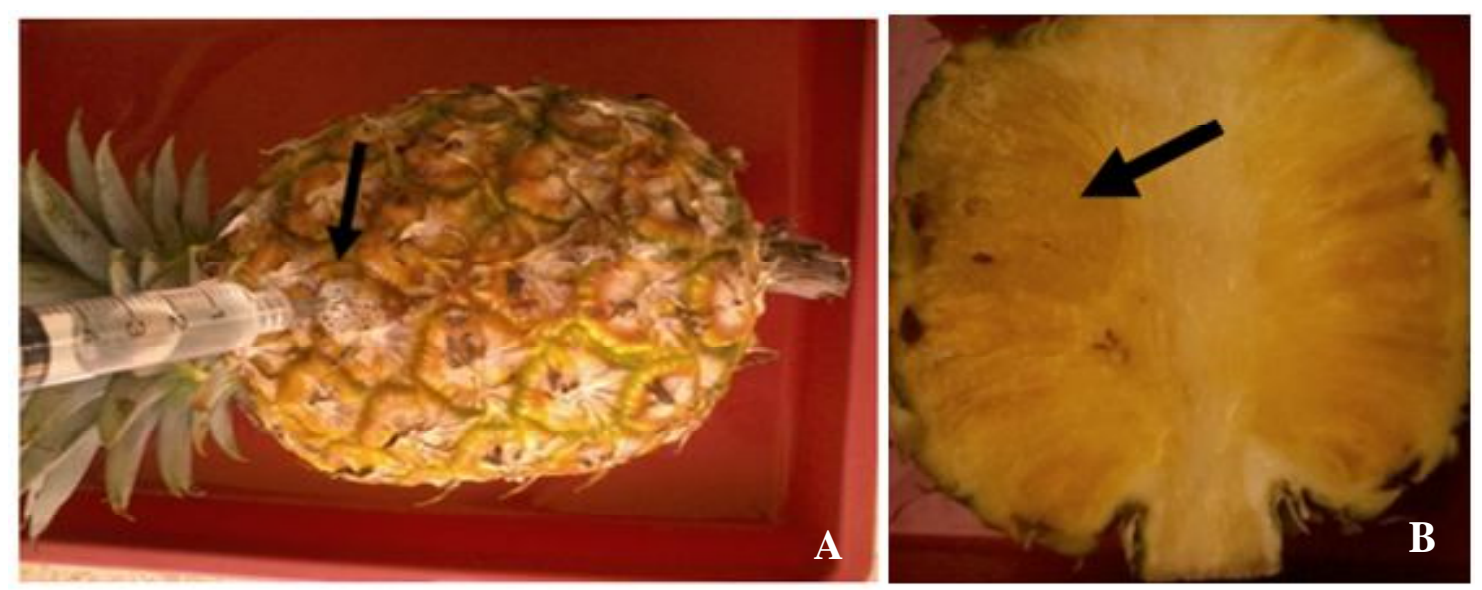

Figure 4. Symptoms of inoculated fresh fruit: fruit skin surface appeared wet and produced gas bubbles(A), many cavities were formed within its sceletal fibres (B)

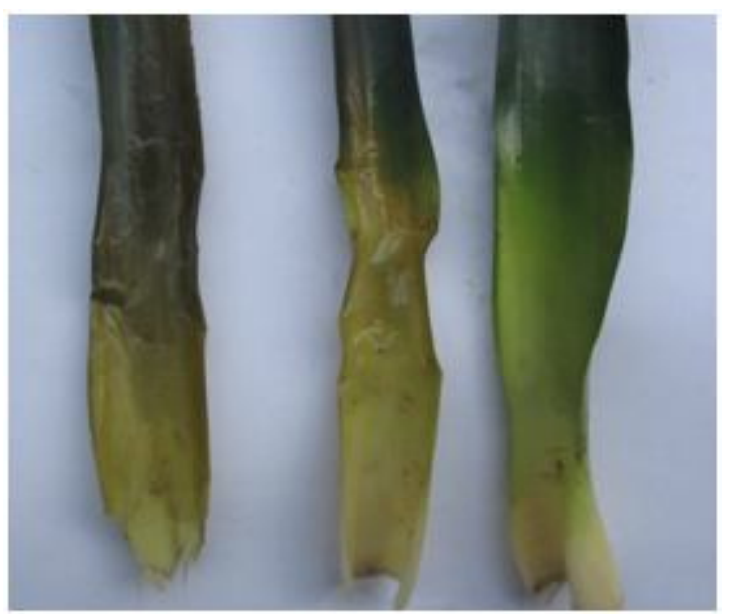

Figure 5. The symptom of heart rot in base part of the leaf 


\section{CONCLUSION}

Based on observation on the disease symptoms and signs, results of pathogenicity test and growing-on test, and comparison with available references (APPD, 2011; Bartholomiew et al., 2003; DoA, 2009; Kaneshiro et al., 2008), we believe that the disease is the pineapple fruit collapse cause by Erwinia chrysanthemi.

\section{ACKOWLEDGMENT}

The outhors thanked NTF company for funding this work. We also thanked Prof. Dr. F.X.Susilo for reviewing this article and Dr. Suskandini Ratih who assisted in the early diagnosis proccess.

\section{REFERENCES}

APPD. 2011 Australian Plant Pest Database. Plant Health Australia. www.planthealthaustralia.com. au/appd. Accessed December 2013.
Bartholomew DP, Malezieux E, Sanewski GM, \& Sinclair E.2003. Inflorescence and fruit development and yield. In: Bartholomew DP, Paull $\mathrm{RE}$, \& Rohrbach KG (Eds). The Pineapple Botany, Production and Uses. Pp.167-202. CABI Publishing.

DoA. 2009. Fresh Pineapple Fruit of Malaysia. Crop Protection and Plant Quarantine Division, Department of Agriculture, Malaysia.

Kaneshiro, WS, Burger M, Vine BG, de Silva AS, \& Alvarez AM. 2008. Characterization of Erwinia chrysanthemi from bacterial heart rot of pineapple out break in Hawaii. Plant Dis. 92: 1444-1450.

Korres AMN, Ventura JA, \& Fernandez PMB. 2010. First report of Bacterium and yeast assosciated with pineapple fruit collapse in Espirito Santo State, Brazil (Abster.). Plant Dis. 94(12): 1509. 